Powered by the state or finance? The organization of China's carbon markets

\author{
Alex Y. Lo \\ Corresponding author \\ Urban Research Program \\ Griffith School of Environment \\ Griffith University \\ Gold Coast, QLD 4222, Australia \\ Email: alex.lo@griffith.edu.au \\ Telephone: +61 755527419 \\ Michael Howes \\ Urban Research Program \\ Griffith School of Environment \\ Griffith University \\ Gold Coast, QLD 4222, Australia
}

Please cite this article as:

Lo, Alex Y. \& Howes, Michael (2013) Powered by the state or finance? The organization of China's carbon markets, Eurasian Geography and Economics, 54:4, 386-408

Link to this article: http://dx.doi.org/10.1080/15387216.2013.870794 


\title{
Powered by the state or finance? The organization of China's carbon markets
}

\begin{abstract}
This paper reviews the progress of carbon trading in China and examines the involvement of the state and financial sectors. China witnessed proliferation of domestic carbon markets before attempting to institutionalize the carbon trading regime. Direct and strong government intervention is a key feature of this process. The domestic carbon markets are primarily created, shaped, and operated by the central and local governments supported by a cohort of macroeconomic planners, local economic agencies, state-owned financial institutions, and business organizations with government backing. Key market players are institutionally dependent on the state - much more so than in capitalist economies. Private investments have not been adequately and effectively mobilized due to unfavorable economic, regulatory, and policy conditions. Nonstate financial actors are not an active and influential player. This indicates a hierarchical relationship between the state and finance and a clear asymmetry of power in the organization of China's carbon markets. These observations constitute a notable difference to the international carbon markets, which are subject to the strong influence of private finance. China has put the market-based policy instrument of carbon trading under a substantial concentration of state power. The findings have important implications for understanding the rise of carbon markets in non-traditional capitalist economies.
\end{abstract}

Keywords: carbon market, emission trading, carbon finance, climate change policy, political economy, China. 


\section{Introduction}

Carbon markets are places where greenhouse gas (GHG) emission permits and certified emission reductions are traded as a standardized commodity in accordance with regulations and agreements, such as the European Union (EU)'s emissions trading scheme (ETS) or the Kyoto Protocol's Clean Development Mechanism (CDM). In less than ten years they have ascended to the dominant form of institutions for climate change mitigation (Ellerman, Convery, and Perthuis 2010; Grubb 2012; Mol 2012; Spaargaren and Mol 2013). Global carbon trades recorded a soaring market value of US\$176 billion in 2011 (Kossoy and Guigon 2012). The world's largest compliance carbon market is the EU ETS, which is worth US\$148 billion and has just entered Phase III (2013-2020) of its implementation. Progress has also been made outside Europe, with ETSs emerging in New Zealand, Tokyo (Japan), Australia, California, ten northeastern states of the U.S., British Columbia, Quebec (Canada), and South Korea (Flannery et al. 2012; Productivity Commission 2011). What is common in these schemes is that they all operate in a mature capitalist economy governed by a liberal democratic state.

The rapid growth of carbon markets in the liberal-capitalist world is a product of a coalition of financial, political, and environmental actors who have common interests in turning GHG emissions reductions into a new commodity (Bumpus and Liverman 2008; Lo and Spash 2012; Newell and Paterson 2010; Paterson 2010, 2012; Spash and Lo 2012). Paterson (2012) argues that the power of the financial sector plays a critical role. Carbon markets have become popular because they have enabled the formation of such a powerful political coalition favoring GHG emissions reductions and enabled businesses to imagine a cycle of investments, profits, and growth centered on these markets. The success of emissions trading "lies in part in its capacity to identify such a sector - finance - that can grow precisely because of climate policy" (Paterson 2012, 89). Carbon markets flourish because they allow capital to accumulate as GHG emissions are mitigated. Prospects for a positive-sum game motivate the coalition of actors to promote carbon markets.

China's carbon markets, however, operate in a different context. In October 2011 the Chinese central government appointed seven pilot ETSs and declared interest in introducing a national ETS. The prospective Chinese ETS is expected to inaugurate the world's second-largest carbon market after the EU ETS and mark a major step forward in creating a global carbon 
market. Yet, behind the looming prospects are numerous enduring problems. Domestic demand for emission reductions remains weak, as the country is not subject to legally binding emission targets and corporate voluntary commitments on emissions abatement are negligible. The carbon markets suffer from a dearth of actual trading as a consequence (Adams 2013; Han et al. 2012; Yu and Elsworth 2012).

Furthermore, the state machinery is not designed to run market mechanisms (Gilley 2012; Lo 2013). China has formally embraced the notion of "socialist market economy" since its $14^{\text {th }}$ National Congress held in 1992. The post-Mao market reforms have seen the state retaining substantial control over critical industries, commodity markets, and the economy generally. The authoritative governing practice could undermine the capacity of economic and market institutions to support the use of market-based policy instruments for mitigating environmental impacts. This begs that question about how the Chinese domestic carbon markets are being organized and progressing under the substantial concentration of power in the state.

The concentration of state power indicates a notable departure from the view that carbon markets are primarily powered by a finance-led coalition. This paper attempts to stimulate discussion on other possibilities by ascertaining the extent to which Chinese financial and stateeconomic institutions are involved in constructing domestic carbon markets. To address this issue we solicited and analyzed relevant official announcements, government policy guidelines and work plans, media stories, and professional reports related to the regulation and financing of carbon markets in China. This paper presents an assessment of the level of involvement by state agencies, environmental actors, and private financial institutions.

As China has ascended to the larger national source of GHG emissions and the secondlargest economy worldwide, the way in which its carbon markets operate will have significant implications for climate mitigation at the global level using market mechanisms. Our analysis is not only useful for ascertaining the unique properties of the ETSs situated in this incomplete capitalist economy (i.e. China), but also has broader implications for understanding the ETSs being considered in other developing countries.

We begin by describing in detail the carbon trading activities in China and outline the two phases of market development. This is followed by separate discussions on the role and 
influence of the state, environmental actors, and finance in developing the carbon markets. The conclusions summarize and highlight the importance of state involvement in the market development process.

\section{Market Building: Progress in China}

Market proliferation (2005 - 2010)

China entered into the carbon trading community as a primary producer of emissions reductions under the CDM of the Kyoto Protocol. The CDM allows developed countries to meet their emissions reduction targets at lower costs by providing financial support to projects that cut or avoid GHG emissions in developing countries and then acquiring emissions reductions that satisfy the criteria approved by the CDM Executive Board, known as Certified Emission Reductions (CERs).

China is the largest supplier of CERs, currently hosting 52 percent of the projects registered under the CDM and producing 61.9 percent of the expected CERs from registered projects. Active involvement in the CDM was preceded by some initial hesitation (Han et al. 2012). The Chinese government did not endorse the implementation of CDM until 2004, after the first project had already been registered in Brazil. From mid-2005, CDM activities received increasing support and better coordination by national government agencies and quickly gained momentum across the country (Han et al. 2012; Zhang 2010). The first Chinese project was successfully registered by the CDM Executive Board in June 2005. From 2006, the number of CDM projects experienced exponential growth.

Figure 1 displays supporting data extracted from the Chinese CDM Project Database. In 2005 only a handful of projects were granted national approval, which is a necessary condition prior to requesting CDM registration. The number of nationally approved projects jumped from 236 in 2006 to 769 in 2007. The exponential growth peaked in 2008, then contracted. This

suggests that CDM project developers rushed into the market between 2006 and 2008. Activity has cooled off since 2008 but bounced back toward the end of 2012, when the first commitment period of the Kyoto Protocol came to conclusion. 


\section{[FIGURE 1 ABOUT HERE]}

The early years of CDM implementation in China proved to be a learning period for all market participants. The growth in the number of local firms and project developers participating was not followed by a parallel increase in the quality of projects. This is demonstrated by the decline in the rate of successful registration during the period 2006 to 2008, which is estimated by dividing the number of CDM registrations by national approvals (Figure 1). The rapid expansion of the domestic carbon markets exposed the problem of nationwide shortage of expertise and experience in building emission reductions projects in accordance with the highly technical and demanding CDM operational rules (Qin 2012). More project developers competed for a limited supply of qualified consultancy services, and the government itself had only begun to learn the CDM requirements. Furthermore, the CDM Executive Board tightened project assessment criteria after the first few years of operation. Many nationally approved projects that would have been approved in early days were eventually rejected due to additionality ${ }^{\text {ii }}$ concerns, with wind energy projects as the notable example (Lewis 2010; Lütken 2010). Transparency issues related to GHG data monitoring, reporting, and verification in China have also been raised in international climate change meetings. The rising enthusiasm in the CDM did not come with successful outcomes until the end of the 2000s.

Another indicator of rapid expansion is the number of carbon exchanges ${ }^{\mathrm{iii}}$. Domestic carbon exchanges proliferated a few years after the country started its CDM program. In 2008 state leaders expressed an interest in domestic carbon trading in internal meetings (Huang 2013). Since then China has witnessed a blossoming of domestic carbon exchanges: at least 42 have been established with an aim of supporting the flourishing carbon trading business in China (listed in Table 2 in Section 3). The first lot of establishments emerged in major cities and was immediately followed by a number of second-tier cities and even counties.

These carbon exchanges, however, run short on trading activities. Reports suggest that, for instance, only three millions tonnes of carbon emissions were traded in the China Beijing Environment Exchange (CBEEX), the flagship carbon market located at the nation's capital, in its first three years, falling short of the daily trading volume in Europe (China Business News 2011). Few transactions have taken place in its counterparts in Changsha and Shenzhen since their inception. Adams (2013) describes the Shenzhen exchange as "hardly a hub of activity" 
with a "trivial" number of carbon credits having changed hands in sporadic transactions. An unsurprising outcome of this overdevelopment is premature closure of smaller exchanges (Xinhua News Agency 2011). Single County, for example, is a small, traditional agricultural county located at the southwest of Shandong Province and has some capacity for renewable energy development. However, it has neither an active financial service industry to support carbon trading nor strong demand for emissions reductions. Established in 2010, the Single County Carbon Exchange reportedly shut down its trading operation in less than one year (Xinhua News Agency 2011).

The overdevelopment of carbon exchanges is ascribed to a structural imbalance between supply and demand. Key problems include the absence of binding emission caps and strong voluntary efforts. Most Chinese firms have no obligation to hold carbon emissions credits for the pollution they produce. Besides CDM activities, domestic carbon trades have been mainly driven by voluntary commitments. Yet the reality is that very few Chinese firms have strong motivations to purchase emission reduction credits to address corporate social responsibility (Adams 2013; Huang 2013). Weak domestic demand has undermined the scale and viability of individual carbon exchanges. In the absence of trading opportunities the prospects of these carbon exchanges are bleak.

Carbon trading activities received considerable attention and resources during the second half of the 2000s. Yet it was a quantitative growth in the number of market participants and facilities. Quality was not assured because rules remained unclear, market demand stayed low, and policy coordination was far from adequate. The mixed outcomes prompted the central government to discipline and institutionalize the carbon markets by introducing a series of trial regulations and policy programs in 2011.

\section{Trial Institutionalisation (2011 onward)}

\section{Central coordination}

Market-based policy instruments were not the preferred option of the Chinese central government in dealing with climate change. Frustrated with the unsatisfactory outcomes of direct 
regulation, Chinese policymakers became increasingly sympathetic towards market mechanisms. Although China's experience with $\mathrm{SO}_{2}$ emission trading was not a great success (Chang and Wang 2010; Tao and Mah 2009), policymakers decided to embark on another environmental market experiment at an even larger scale.

In October 2010 the State Council, the chief administrative body of China, issued a formal circular known as "Decision of the State Council to Accelerate the Development of Emerging Strategic Industries" (State Council 2010) that included a brief statement affirming a role for domestic carbon trading. This commitment received political blessing at a higher level when the $12^{\text {th }}$ "Five Year Plan" $(\mathrm{FYP})^{\text {iv }}$ was ratified at the $11^{\text {th }}$ National People's Congress in March 2011. The $12^{\text {th }}$ FYP recommended, among other things, progressively establishing a domestic carbon market for China. The FYP gave impetus and political legitimacy to the construction of carbon markets in China.

This commitment was followed by the implementation of supportive administrative arrangements. In October 2011 the National Development and Reform Commission (NDRC), the macro-economic branch of the State Council, issued a single-issue notice revealing more detail about the way forward; i.e. running pilot ETSs at selected sites (National Development and Reform Commission 2011). The short-term goal was to establish trans-provincial and transregional ETSs in transition to a national scheme by 2015-2016. The central government has authorized a concrete action by setting up regional cap-and-trade systems, which require introducing limits on total emissions. Absolute emission caps had previously been seen as unacceptable by government officials at all levels because of the associated macro-economic and ideological implications (Zhang 2007). Implementing ETSs is therefore a critical move and indicates a key milestone in the history of Chinese climate policy.

The NDRC appointed seven ETS pilot sites across the country, including two provinces (Guangdong and Hubei) and five cities (Beijing, Tianjin, Shanghai, Chongqing, and Shenzhen). They account for 25.4 per cent of China's national GDP and 18.5 per cent of its population. ${ }^{\mathrm{v}}$ Table 1 provides a list of key economic indicators and the assigned emissions reduction targets of these provinces and cities. They vary in economic capacity, political importance, and geography. In the north, Beijing is the nation's capital and political center, and the neighboring Tianjin is a northern industrial economic center. Shenzhen is an economic engine of southern 
China, a "Special Economic Zone," and a forerunner of the post-Mao economic reforms. Shanghai at the eastern coast is a major center of financial activity for the country and aspires to become an international financial hub, whereas the inland Chongqing leads the south-western regional economy and is known for its high urban temperatures. Guangdong is the biggest and wealthiest province of China at the southern coast, whereas Hubei is at a lower development stage and geographically situated at the center of the country. These provinces and cities have been assigned different energy and carbon intensity targets, and all have established their own carbon or environment exchanges. The diverse locations allow the notion of ETS to be tested against different economic and institutional constraints prior to official adoption of a national scheme (Qian and Jin 2012).

\section{[TABLE 1 ABOUT HERE]}

These provincial and municipal governments have assumed responsibility for designing the pilot ETSs. They have been given the discretion to determine the emission targets, the permit allocation rules, the sectors to be covered, and to develop both the systems of governance and market infrastructure. Core features of the pilot ETSs are listed in Appendix Table A1. The pilot schemes were due to commence in the second half of 2013 to early 2014, and the proportion of local GHG emissions covered ranges from 35 percent to 60 percent. More than 600 firms in Guangdong and Shenzhen will be included, as well as 420-600 in Beijing and less than 200 in the other regions. Heavy industries and the energy sectors are targeted. Initially most of the emission allowances under the ETSs will be freely allocated to selected industries based on historic emissions, but these may eventually shift to an auctioning mechanism. Carbon offsets can be used for compliance only up to 10-15 percent of the assigned emissions reduction targets. Provincial or municipal GHG emissions will be capped under the pilot ETSs, but currently there is no clear official information on the level of caps.

Domestic ETSs in China are not limited to these seven trial zones. Other key cities, such as Hangzhou (Zhejiang Province) and Chengdu (Sichuan Province), have also announced emission trading plans. A new round of market proliferation is set to boom, but lessons from the over-development in the early years are still fresh in mind. Central coordination is underway to stabilize and discipline the expanding markets. This is supported by a series of measures, two of which are described below. 


\section{Strengthening regulation}

The unchecked proliferation of exchanges may create several financial risks. In November 2011 the State Council released a decree entitled the "Decision of the State Council to Strengthen the Discipline of Various Exchanges to Avoid Financial Risks" (State Council 2011a). This expressed concerns about the unsatisfactory management practices of local exchanges and governments. The State Council articulated a strong position on disciplining local financial markets and establishing market order by strengthening central control. One of the new requirements is that no establishment should be officially called an "exchange" without prior approval from the central government - a move clearly targeted at carbon markets and carbon exchanges.

Six months later the central government turned its attention to voluntary carbon markets. In voluntary carbon markets, private or public entities acquire GHG emissions reductions on a voluntary basis despite not having a legal obligation to curb emissions. The central government appears cautiously sympathetic toward establishing voluntary carbon markets (Huang 2013). Although there are various efforts toward promoting voluntary offsetting of GHG emissions, progress is limited partly because the markets remain fragmented and unstructured. Apart from weak market demand, one of the main issues is the lack of clear guidelines and transparent procedures that define responsibilities and criteria for the development and registration of voluntary emissions reduction projects. In June 2012 the NDRC released and circulated a notice entitled the "Provisional Arrangements for Voluntary Greenhouse Gas Emissions Trading" among relevant government agencies and local authorities. This administrative document specifies nearly 30 substantive guidelines for the regulation of domestic voluntary carbon markets. The guidelines involve issues about the designation of authority and responsibility, the registration procedures for offset projects, and the verification and reporting requirements.

This section has described two phases of the early development of China's carbon markets. During the second half of the previous decade, emerging carbon markets were overwhelmed by the influx of investment that led to the market overheating. From 2011 onward, the government has attempted to institutionalize carbon trading and strengthen the regulation of 
domestic carbon markets. The next section demonstrates how this market-building process was dominated by state agencies and their institutional dependents, whereas the involvement of financial industries, as discussed later, has had less impact.

\section{Pervasive Influence: The Involvement of the State}

In capitalist economies, financial institutions and businesses organize carbon markets via a coalition with state and environmental actors (Paterson 2010, 2012; Newell and Paterson 2010). The governing of carbon markets within China demonstrates significant differences in terms of the engagement and influence of these actors. This section elaborates on the role of the government.

China's carbon markets were initially built upon the CDM, which is governed by international institutions. As the CDM market proved a partial success, many institutions and actors in China started looking for domestic opportunities, such as voluntary carbon trading. In theory, governance of voluntary markets should be independent of the state in the developed world. As Spaargaren and Mol $(2013,183)$ explain, "Voluntary markets are not under the direct control of state agencies, and they cannot be abolished by states when performing poorly. They are regulated through private or moral forms of environmental authority."

In China, however, state control has never been removed from the domestic voluntary carbon markets. Although financial companies and international exchanges are involved in the establishment of major carbon exchanges in China, governments act as the main institutional driving force. Within the country, there is keen competition for new economic opportunities among local jurisdictions. Carbon markets manifest themselves as new arenas where local governments compete to attract the first lots of carbon trades and demonstrate their capacity to capture the new commodity (i.e. carbon offsets). Han et al. $(2012,21)$ anticipate that the number

of Chinese carbon exchanges might eventually exceed one hundred, and that the rapid growth is driven by jurisdictional competition: “... the [carbon] exchanges are eager to establish themselves with talented staff and substantive business models so that they become cornerstones of any national or regional carbon market developments when the central government eventually take the lead." 
Anticipation of a national ETS also prompted active responses from local government chiefs, who are appointed by the central government and keen on making their jurisdictions a "cornerstone" of Chinese carbon markets to demonstrate their good performance. Wang, Liu, and Chen (2012) conclude that this fierce competition has led to the chaotic proliferation of carbon exchanges in the early years.

While the Chinese voluntary markets are fragmented and many are not active, the one thing that they all have in common is strong government involvement. Although carbon exchanges in China are registered as corporate environmental equity trading platforms and not formally owned by the government, they are characterized by strong government backing (Han et al. 2012). Most of these exchanges are owned or authorized, directly or indirectly, by government bodies (Huang 2013). Table 2 provides a list of carbon exchanges that we were able to identify. The majority of them are state-owned or state-controlled entities (including enterprises, equity exchanges, and research institutes) and have government bodies as their shareholders (see Appendix Table A2 for a full list). Active government involvement is particularly obvious in flagship exchanges, such as Beijing, Tianjin, Shanghai, and Guangzhou, which are created as a joint venture between local governments and state-owned enterprises (SOEs).

\section{[TABLE 2 ABOUT HERE]}

The CBEEX, for example, was established with formal approval from the Beijing government by the state-authorized Beijing Assets and Equity Exchange and three other stateowned or state-controlled enterprises; namely, the CNOOC New Energy Investment Company Limited, the China Guodian Corporation, and the China Everbright Investment Corporation. The Shanghai Environment and Energy Exchange is owned by the stated-owned Shanghai United Assets and Equity Exchange, the Ministry of Finance, and a few SOEs. The biggest shareholder (53 percent) of the Tianjin Emission Rights Exchange is the China National Petroleum Corporation - a state-owned oil giant. These exchanges are subject to indirect state influence through various institutions backed by the government. In contrast, government intervention is less explicit in the establishment and operation of international climate exchanges such as the European Climate Exchange and the Chicago Climate Exchange. 
State ownership and control have another structural implication. Many of the key industrial sectors and enterprises that are covered by the pilot ETSs are also owned or controlled by the state. The power market in China, for example, is dominated by SOEs, and company chiefs are appointed by the government (Zhao, Wang, and Wang 2012). The power industry is one of those most strongly affected by carbon prices due to the high carbon intensity in the coalbased production process. The oil sector and other capital-intensive industries are in a similar situation. Corporate participants in the voluntary markets are also dominated by SOEs. According to Huang (2013), most of the corporate members of the "Carbon Neutral Alliance," China's first exchange-corporation association, are financial SOEs. This means that many market participants are institutionally highly dependent on the government. In contrast, equivalent organizations in other major economies are largely business-led, such as the U.K.'s Emissions Trading Group. The Chinese carbon markets are characterized by a hierarchical relationship between the regulator and many regulated enterprises.

Carbon end-user markets are also subject to strong government intervention. Under a carbon price, end-users are expected to adjust their consumption and reduce their emissions in response to price signals. Yet the cost transfer mechanisms in China are distorted. Power prices are moderated by the central government through the Department of Price. Power companies are not entirely free to pass the cost impacts of carbon prices to electricity users by raising retail prices - instead, the central government has the authority to decide. The private sphere in the domestic carbon markets is constrained by the state.

State influence is pervasive in Chinese domestic carbon markets. Market construction, operation, and participation are dominated by state actors; namely, central economic agencies,

local governments, and SOEs. On the other hand, the role of environmental actors, including environmental authorities and non-governmental organizations (NGOs), in the domestic market community are less influential, a point to which we now turn.

\section{Secondary Players: The Involvement of Environmental Actors}

China's climate change policies have been driven by economic and security concerns rather than broader environmental commitments (Lewis 2010; Lo 2010; Tsang and Kolk 2010). In keeping 
with the goal of continuing economic development, carbon trading is seen as part of the broader macroeconomic strategy for China (Lo 2013). In the governing of carbon markets, there are situations where economic agencies oversee or even displace environmental agencies.

\section{Environmental authorities}

Under the CDM, each participating country nominates an organization, known as Designated National Authority (DNA), to authorize and approve participation in CDM projects before submitting them to the CDM Executive Board for registration. All DNAs are government agencies or their delegates. The majority of them are environment departments or ministries, or agencies with an explicitly stated environment-related portfolio, ${ }^{\mathrm{vi}}$ regardless of the scale of country or the type of economic system. China is one of the few exceptions, because an economic planning agency, the NDRC, is charged with granting national approvals for proposed CDM projects. This does not, however, mean that environmental aspects are excluded from consideration. As well as being responsible for economic and development policies, the NRDC has a subsidiary climate change department which is the executive arm of the Chinese DNA. This organizational arrangement allows the integration of climate change considerations into economic policymaking processes. The structure is still hierarchical, and the climate change department is directly accountable to and supervised by senior economic officials whose primary responsibility is to promote economic development.

Interestingly, the Ministry of Environmental Protection (MEP) is independent of the NDRC system and not oriented to economic imperatives. The MEP does not play a lead role in formulating climate change policies or setting up carbon markets. China launched the National Climate Change Program in 2007 and released a climate change white paper in 2008 (National Development and Reform Commission 2007; State Council 2008). None of these key policy documents makes reference to the MEP or its predecessor (Lo 2010). Although carbon trading has been written into the comprehensive $12^{\text {th }}$ FYP (which is approved by the National People's Congress), neither carbon trading nor carbon markets (nor even "carbon" or "climate change") is mentioned in the thematic $12^{\text {th }}$ FYP for National Environmental Protection released by the State Council (State Council 2011b). The designated environmental agency, the MEP, is clearly not 
the lead authority for climate change, and carbon trading is not recognized in the national guidelines dedicated to environmental protection. The state environmental apparatus operates at a distance from the carbon market regime.

Local environmental agencies are also largely absent from the pilot ETS working groups. We solicited the ETS implementation plans of four selected trial zones (i.e. Chongqing, Guangdong, Hubei, and Tianjin) ${ }^{\mathrm{vii}}$ and investigated the involvement of local environmental agencies, such as environmental bureaus and forestry bureaus, etc. These implementation plans included a task assignment list or an explicit statement of responsibilities among different local government departments. Almost all of the ETS preparation tasks listed in these documents has been assigned to the economic or financial arms of government, notably the municipal or provincial Development and Reform Commissions (local equivalents of NDRC). Environmental agencies were only occasionally involved and often put at the end of the list (indicating lower priority). As an example, the official work schedule attached to the Guangdong ETS implementation plan is included in the Appendix Table A3. The work schedule illustrates the dominance of economic and financial authorities in the preparation and operation of the pilot project. Such an organizational arrangement varies from other ETSs, such as those of the Tokyo Metropolitan Government (Tokyo Metropolitan Government 2010) and the Australian Federal Government (Australian Government 2011), which are coordinated and administered by an environmental or climate change department.

\section{Environmental NGOs}

China's centralized environmental policy-making practice does not leave much scope for NGOs to take on key national issues (Muldavin 2013; Richerzhagen and Scholz 2008), and they have little influence on the country's climate policy regime (Liu 2009; Lo 2010). The governance of domestic carbon markets has been consistent with the traditional top-down approach (Qian and Jin 2012). Participation of NGOs has been restricted to providing finance, raising awareness, and organizing capacity building activities for interested businesses or individuals (Huang 2013; Yu 2012). Successful examples include the World Wide Fund China and the Global Environmental Institute (a China-based NGO). However, these NGOs are not directly involved in competitive 
market activities, such as the transactions of carbon credits (Huang 2013). Unlike international NGOs, which have better access to policy communities and large corporations (Newell and Paterson 2010), NGOs in China do not play a key role influencing the design of rules for carbon markets.

An example is the formulation of verification standards in the voluntary carbon market. Tradable emission reductions are assessed by an independent third party to ensure that the claimed reductions are real, verifiable, and additional so that they can be used to offset an equal volume of emissions generated elsewhere. Many international standards involve NGOs in the development process. The Gold Standard, for instance, was established in 2003 by the WWF International and has received recognition by more than 80 NGOs.

China attempted to invent its own standards. In December 2009 the CBEEX launched the "Panda Standard," which was the first voluntary carbon standard made in China. The Panda Standard verifies voluntary emission reductions, targeting agriculture, forestry and other land use GHG offset projects. It was co-founded by BlueNext, a French-based environmental exchange, and the China Forestry Exchange (a state-owned company). The Asian Development Bank is the only corporate partner. The establishment of the Panda Standard did not directly involve domestic environmental NGOs, although its technical committee includes an NGO chief as an individual board member. Active engagement of environmental NGOs is not a core feature of Chinese carbon markets.

Although environmental professionals both within and outside the state have put climate change on their agenda, they appear to be merely secondary players following the lead of economic agencies in the building of carbon markets. Newell and Paterson (2010) argue that financiers and large corporations are the game changers in carbon markets. We now examine the role of finance in the carbon markets of China.

\section{Limited Gains: The Involvement of Finance}

The idea that carbon markets are promoted by a coalition of state and non-state actors, notably financiers, is based upon several assumptions. One of these assumptions is that, first and 
foremost, a cycle of economic returns from carbon trading is foreseeable. Financial actors are then motivated to lobby an influential policy or political community which possesses the regulatory and moral power to establish a carbon market to realize those benefits. However, the timing and the top-down approach in which the Chinese carbon markets were organized and commenced did not provide a favorable environment for the mobilization of capital and political investments in carbon trading. The Chinese carbon markets entered the process of institutionalization in an uncertain period so that the strong leadership of finance could not be taken for granted. We elaborate on this in two separate subsections.

\section{An awkward moment: Big commitment amidst huge uncertainties}

China pledged to institutionalize its domestic carbon markets in early 2011 and approved pilot ETSs later that year. Optimism in the global economy, carbon trading, and the larger environment declined toward the end of 2011 and 2012. This is not the best time for China to step in, given that Chinese policymakers used to be very cautious toward carbon trading as a climate policy instrument (Wu 2011; Zhang 2007).

In 2009, carbon trading entered an uncertain period when countries started grappling with global recessions (Perdan and Azapagic 2011). December 2009 is also remembered for the failure to produce substantive agreements on post-2012 Kyoto commitments in the United

Nations (UN) climate change conference at Copenhagen, ${ }^{\text {viii }}$ which could have resulted in premature suspension of the CDM and created adverse impacts on market demand for emissions reductions.

In 2010, there was a gradual decline in confidence in the market due to the lingering economic uncertainties and the lack of substantive global agreements. Federal proposals for a national cap-and-trade system were withdrawn in Australia and the U.S, both of them being the two highest per capita GHG emitters. Australian federal government encountered legislative hurdles and finally decided to defer a controversial ETS proposal. Kevin Rudd lost the prime ministership and his successor, Julia Gillard, initially appeared to reject the idea of Australian ETS, which later proved to be another political disaster. In the U.S., the Waxman-Markey bill, 
which had emissions trading as its centerpiece, was defeated in the Senate. After mid-term elections in November 2010, President Obama put his preferred cap-and-trade program on hold.

In December 2010, the Japanese government indicated its intention to shelve a planned mandatory cap-and-trade scheme, which would have become Asia's first national ETS (Perdan and Azapagic 2011). Similar schemes were also watered down in Canada, New Zealand, and South Korea. In the U.S., one of the major climate exchanges, the Chicago Climate Exchange, shut down its carbon trading program due to inactivity in U.S. carbon markets. The year concluded without substantive agreements on international and national emission reductions in the Cancun climate change conference, and consequently, mounting uncertainties over the post2012 Kyoto commitments. Pessimism toward the future of the global emissions reductions effort continued to loom.

In March 2011 a major earthquake and tsunami hit Japan, leading to the disastrous Fukushima nuclear accident. This catastrophic event raised public concern about the extensive use of nuclear energy needed to sustain deep cuts in GHG emissions (Rudolph and Schneider, 2013), effectively killing off the Japanese ETS. Regional carbon trading in the U.S. also entered a difficult time. In early 2011, several U.S. states hesitated to act on their joint agreements to pursue a regional ETS (Perdan and Azapagic 2011). In Europe, the sovereign debt crisis remained unresolved. Some EU Member States promised large-scale austerity measures in order to secure bailout loans. Financial markets expressed serious doubt about the credit-worthiness of individual Member States. Market demand for emissions reductions diminished as a result of the lingering uncertainties over the European economy and the contraction of economic activities. These uncertainties were reflected in falling carbon prices recorded in various carbon markets (Newell, Pizer, and Raimi 2013). This year, again, concluded with the failure to confirm the extension of the Kyoto Protocol at the annual UN conference.

China announced its carbon trading program amidst these bleak global conditions. Figure 2 highlights the timing of the three Chinese official statements explicitly indicating an intention to create a domestic carbon market, relative to the important international events mentioned above. China officially expressed its interest in carbon trading in October 2010, despite the U.S. and Australia stepping back from their own ETS plans earlier that year. Informal sources suggest that the decision was made in June or July 2010, six months after the 2009 Copenhagen 
conference ( $\mathrm{Li} 2010)$. The commitment was formally written into the paramount $12^{\text {th }}$ FYP in March 2011, while ETSs were encountering hurdles in other major economies, notably the U.S. and Japan. Over the rest of the year China's ETS plan was unaffected by the impacts of the global recessions and the Eurozone crisis. The EU ETS has been the main purchaser of CERs, and China is their dominant exporter. The collapse of CER prices and declining optimism, however, did not erode the Chinese government's resolve to run pilot ETSs. From 2012, governments of the seven trial zones continued to work out their ETSs when the UN conference stagnated and CER prices fell to record lows.

\section{[FIGURE 2 ABOUT HERE]}

Interestingly China's confidence in carbon trading and actions ran opposite to global political and economic tendencies. The unusual responses on the part of China are ascribed to the strong will of the state to raise its influence in global climate governance and carbon markets (Lo, 2012, 2013). The role of finance also warrants attention.

The market uncertainties throughout 2009-2011 gave little momentum and reduced the need for businesses to undertake aggressive emissions reduction. Financiers found no strong market demand for carbon credits. As shown in Figure 2, markets were shut and prices collapsed. This offered little motivation for financial actors to promote carbon trading in China. CDMrelated activities dominated the daily business of Chinese carbon exchanges, but before 2012 there was widespread concern that the CDM would cease to operate (Lewis 2009). The prospects of the Chinese project-based market (i.e. CDM) were yet to be clear. The profitability of the new allowance market, i.e. the planned Chinese ETS, was also under a big question mark. Effective cap-and-trade systems require either the enforcement of binding emission limits or the existence of strong voluntary commitments to create market demand. In China, however, there is considerable political resistance to introducing an emission cap at the national level due to its macro-economic and ideological implications. In addition, few firms have demonstrated a sense of corporate social responsibility and commitment to voluntary actions for the climate (Lo 2010; Huang 2013). These are the reasons for the failures of Chinese climate exchanges in attracting substantive market deals. Under these unfavourable economic and political environments, making economic benefits from carbon finance were hardly foreseeable in China - at least not until the end of 2012. 
China publicly advocated carbon markets when global markets stumbled and financial pessimism loomed. The external economic environment provided limited impetus and incentives for engaging profit-seeking financial actors in such a new market. Within the country, financial actors are also not as active and powerful as their counterparts in the U.S. and Europe.

\section{Low incentives for non-state finance}

Non-state economic actors do not actively engage in environmental issues generally (Buckingham and Jepson 2013; Mol 2006). Mol (2006, 52) has noted that in China, economic and financial institutions such as insurance companies, banks, and business associations "have virtually no role to play in advancing environmental interests." According to Mol (2006), this is because these institutions feel no pressure or see any market opportunity from active engagement. This view accurately describes the current situation of climate finance and specifically carbon trading in China.

The 2012 China Climate Finance Report has indicated that public funds currently dominate the total investment in climate finance in China (Wang, Liu, and Chen 2012; see The Climate Group [2013] for a concise English version). In 2011 state-owned banks offered US\$294 billion and direct government climate spending amounted to US\$41 billion, whereas mainstream private sector investment, such as domestic and foreign bank loans, accounted for around \$US10 billion (The Climate Group 2013, 2). This shows that private funds are currently not the main source of climate finance in China. There are also no established systems to direct private capital to the carbon financial markets. This stands in contrast to the fact that, globally, private investment was the main source of climate mitigation finance (Grubb et al. 2011).

A number of structural problems have undermined the development of carbon financial industry in China. First, the regulatory and policy systems are not conducive to the deployment

of climate finance. Regulatory standards and official data on emissions are far from complete and consistent, making it difficult for financial institutions to assess the economic and environmental viability or risk of applications. The legal system remains incomplete and fragile. This raises the risk of financial frauds and gives little protection to investors in the event of financial breakdowns (Wang, Liu, and Chen 2012; The Climate Group 2013). 
Second, domestic financial institutions themselves lack both the incentive and capacity for participation. Motivation to finance emission mitigation is low, as climate change is not seen by domestic financiers as a fruitful investment option. Although China's state-owned banks consider climate-related investment as a corporate social responsibility issue, they have yet to include climate impacts as key considerations of business development (Wang, Liu, and Chen 2012, 40; The Climate Group 2013, 4). Investors are not very optimistic about the prospects of financial products linked to climate change. Commercial banks are at a stage of "wait and see" and have only recently set up rudimentary carbon asset management services and funds. Many of them do not have adequate knowledge and expertise in climate finance. Progress is slow in developing climate financial products, such as climate debentures and climate insurance.

Carbon trading is a more specific area of climate finance that requires a functioning market to deliver efficient outcomes. The regulatory and policy environment is, again, the key determinant of success or failure. According to Adams (2013), the central government forbade Chinese banks and some other financial institutions from getting involved in the CDM and appears reticent to allow them to participate in the China's domestic carbon markets. Securities regulators do not view carbon trading as falling under the purview of "finance" and tend not to assume direct responsibility for regulating carbon markets (Adams 2013). Indeed, there has been a "culture of distrust in business," creating considerable institutional barriers to corporations and financiers interested in carbon trading (Wang 2013, 273). Carbon asset management firms, for instance, have no significant impacts on the institutional development of Chinese voluntary carbon markets. Neither the central nor local governments consider those firms as indispensable components of domestic carbon trading systems (Huang 2013). On the other hand, state-owned economic entities have been trusted and given access to resources and opportunities for market participation (as we have shown earlier in this paper).

The market structure in its current form does not appear attractive to businesses and financial institutions. Not many Chinese businesses take corporate social responsibility seriously, and they have no legal obligations to curb their emissions. This leads to low demand for carbon credits and related financial services. On the supply side, Chinese carbon exchanges are currently only allowed to operate spot markets that globally account for only a small share of the carbon trades, whereas futures markets constitute the lion's share (Wang, Liu, and Chen 2012). For 
carbon trading to thrive, exchanges must have the capacity to allow derivatives trading and securities businesses, but the central government is reluctant to offer derivatives and securities because of risk-management concerns (Adams 2013). As specified in the 2011 decree (State Council 2011a), special permissions are required for local exchanges to undertake these activities. The limited trading options are likely to discourage financial investors.

This section has argued that the investment environment for carbon trading in China is not favorable. Prospects for economic gains were uncertain when the concept of emission trading received official political approval. The rudimentary market structure, along with the distorted regulatory and policy environments, do not create strong incentives for private financial actors to more actively participate. It is doubtful that the carbon markets in China are primarily driven by private finance in anticipation of "a cycle of economic returns."

\section{Conclusions}

Carbon markets in China are situated in the context of an incomplete capitalist economy, where state influence is pervasive and financial institutions are not the dominant source of power. Since 2005 CDM activities experienced an exponential growth in China and later domestic carbon exchanges proliferated across the country. Since 2011 China has embarked on institutionalizing carbon trading into the national policy framework. The market building process is characterized by strong government intervention and, increasingly, central coordination.

The fast-growing Chinese carbon markets have a few distinctive features. First, the state, directly or indirectly, dominates and controls the market-building process. Key market players, notably the developers of carbon exchanges, regulated entities, and banks providing climate finance, are largely enterprises or organizations that are institutionally highly dependent on the state. Second, environmental interests are under-represented. Dedicated environmental authorities are not given the primary responsibility for making carbon trading or even climate change policies. Domestic NGOs lack the capacity to engage in competitive carbon market activities. Finally, private investments have not been adequately and effectively mobilized due to the unfavorable economic, regulatory, and policy environments. Financial actors are neither an active nor an influential player in China's carbon markets. 
The domestic carbon markets are primarily created, shaped, and operated by the central and local governments supported by a cohort of macro-economic planners, local economic agencies, state-owned or state-controlled financial institutions, and business organizations with government backing. The contributions and influences of environmental authorities and NGOs and private financial institutions are secondary. The current regime requires major institutional reforms to further mobilize private finance and advance environmental interests.

Certainly the role of the state is always central to make carbon markets possible (MacNeil and Paterson 2012; Spaargaren and Mol 2013). Yet China has demonstrated an asymmetry of power by which the state and non-state and environmental actors are not on a level playing field. Many important domestic financial institutions are under state ownership, where senior executive appointments are directly controlled by local or central Communist Party bodies. Consequently domestic financial institutions merely serve as a policy tool for politicians (Heilmann 2005a, b). Likewise, the lobbying power of other emissions-intensive industries is constrained. Most of the domestic industrial organizations have government backing and many consist of state-owned enterprises, such as the China Electricity Council (Yu 2012). They have access to state leaders and the ability to influence government policy through the immediate party political system. Private financial and economic institutions without backing from government bodies are excluded from the center of power and have not been influential in the policymaking processes.

Unlike major carbon markets rooted in industrialized economies (Paterson 2010, 2012), the coalition of Chinese carbon market actors is led by an authoritative government, and predominantly by economic bureaucrats, whereas the representation and power of environmental actors and non-state financial actors is relatively limited. The relationship between the state and finance is hierarchical in the organization of carbon markets. As a "socialist market economy," China has put the market-based policy instrument of carbon trading under a substantial concentration of state power. The extent to which it is truly "market-based" is a subject of concern for policy-makers in other economies exploring the prospects for linking their domestic ETSs with their Chinese counterpart.

More broadly, these observations open up debates on the recent emergence of carbon markets in non-traditional capitalist economies. Plans for implementing an ETS have been put on schedule or under consideration in other major developing countries such as Kazakhstan, Mexico, 
Brazil, Turkey, and Chile ${ }^{\mathrm{ix}}$. Like China, these potential new participants in carbon trading demonstrate different sorts of state-market relations, governance styles, economic systems, and energy profiles. Such variations are likely to persist and pose enormous challenges for building a global carbon market that would link up the varied emission trading systems in the global North and South. There is a need for scholars and policy analysts who advocate the idea of global carbon trading to undertake further research to identify these challenges and to assess the prospects of an internationally linked global carbon market.

\section{Acknowledgement}

This research was primarily funded by the Griffith Climate Change Response Program of Griffith University through the Seed Funding Program. Part of the fieldwork was supported by a competitive grant awarded by the Academy of the Social Sciences in Australia through the Australia-China Joint Action Program. We appreciate both of the funding bodies and the research assistance provided by Xu Bixia. 


\section{References:}

Adams, M. 2013. Trials and Tribulations: China Experiments with Carbon trading. Hong Kong: The Economist Intelligence Unit.

Australian Government. 2011. Securing A Clean Energy Future: The Australian Government's Climate Change Plan. Canberra: Commonwealth of Australia.

Buckingham, K. and P. Jepson. 2013. "Forest Certification with Chinese Characteristics: State Engagement with Non-state Market-driven Governance." Eurasian Geography and Economics 54: 280-299.

Bumpus, A. G. and D. M. Liverman. 2008. "Accumulation by Decarbonization and the Governance of Carbon Offsets." Economic Geography 84: 127-155.

Chang, Y. C. and N. Wang. 2010. "Environmental Regulations and Emissions Trading in China." Energy Policy 38: 3356-3364.

China Business News. 2011. "Permit Allocations Uncertain, Carbon Exchanges Not Yet through Bottleneck." November 23. Accessed 17 September 2012. http://www.yicai.com/news /2011/11/1219852.html (in Chinese).

Ellerman, A. D., F. J. Convery, and C. D. Perthuis. 2010. Pricing Carbon : The European Union Emissions Trading Scheme. Cambridge, UK: Cambridge University Press.

Flannery, T., R. Beale, and G. Hueston. 2012. The Critical Decade: International Action on Climate Change. Canberra.

Grubb, M., T. Laing, T. Counsell and C. Willan. 2011. "Global Carbon Mechanisms: Lessons and Implications." Climatic Change 104: 539-573.

Gilley, B. 2012. "Authoritarian Environmentalism and China's Response to Climate Change." Environmental Politics 21: 287-307.

Grubb, M. 2012. "Emissions Trading: Cap and Trade Finds New Energy." Nature 491(November 29): 666667.

Han, G., M. Olsson, K. Hallding, and D. Lunsford. 2012. China's Carbon Emission Trading: An Overview of Current Development. Stockholm: FORSE and Stockholm Environment Institute.

Heilmann, S. 2005a. "Policy-making and Political Supervision in Shanghai's Financial Industry." Journal of Contemporary China 14: 643-668.

Heilmann, S. 2005b. "Regulatory Innovation by Leninist Means: Communist Party Supervision in China's Financial Industry." The China Quarterly 181: 1-21.

Huang, Y. 2013. "Policy Experimentation and the Emergence of Domestic Voluntary Carbon Trading in China." East Asia 30: 67-89.

Kossoy, A. and P. Guigon. 2012. State and Trends of the Carbon Market 2012. Washington, DC.: World Bank, 94-100.

Lewis, J. I. 2009. "Climate Change and Security: Examining China's Challenges in a Warming World." International Affairs 85: 1195-1213.

Lewis, J. I. 2010. "The Evolving Role of Carbon Finance in Promoting Renewable Energy Development in China." Energy Policy 38: 2875-2886.

Li, J. 2010. Carbon Trading in Pipeline. China Daily. Accessed August 1, 2013. http://www.chinadaily.com.cn/bizchina/2010-07/22/content_11034422.htm.

Liu, H. 2009. "The Impact of Climate Change on China." In The China Environment Yearbook: Crises and Opportunities, edited by D. Yang. Leiden, Netherlands: Brill, 81-97.

Lo, A. Y. 2010. "Active Conflict or Passive Coherence: The Political Economy of Climate Change in China." Environmental Politics 19: 1012-1017.

Lo, A.Y. 2012. Carbon Emission Trading in China. Nature Climate Change 2: 765-766. 
Lo, A. Y. 2013. "Carbon Trading in a Socialist Market Economy: Can China Make a Difference?" Ecological Economics 87: 72-74.

Lo, A. Y. and C. L. Spash. 2012. "How Green is Your Scheme? Greenhouse Gas Control the Australian Way." Energy Policy 50: 150-153.

Lütken, S. E. 2010. A Grand Chinese Climate Scheme. Copenhagen: Ris $\varnothing$ DTU.

MacNeil, R. and M. Paterson. 2012. "Neoliberal Climate Policy: From Market Fetishism to the Developmental State." Environmental Politics 21: 230-247.

Mol, A. P. J. 2006. "Environment and Modernity in Transitional China: Frontiers of Ecological Modernization." Development and Change 37: 29-56.

Mol, A. P. J. 2012. "Carbon Flows, Financial Markets, and Climate Change Mitigation." Environmental Development 1: 10-24.

Muldavin, J. 2013. "From Rural Transformation to Global Integration: Comparative Analyses of the Environmental Dimensions of China's Rise." Eurasian Geography and Economics 54: 259-279.

National Development and Reform Commission. 2007. China's National Climate Change Programme. Beijing: National Development and Reform Commission.

National Development and Reform Commission. 2011. Notice on the Commencement of Carbon Trading Pilot Projects. (in Chinese). Beijing: National Development and Reform Commission. Accessed September 17, 2012. http://www.ndrc.gov.cn/zcfb/zcfbtz/2011tz/t20120113_456506.htm

Newell, P. and Paterson, M. 2010. Climate Capitalism: Global Warming and the Transformation of the Global Economy. Cambridge: Cambridge University Press.

Newell, R. G., W. A. Pizer, and D. Raimi. 2013. "Carbon Markets 15 Years after Kyoto: Lessons Learned, New Challenges." Journal of Economic Perspectives 27: 123-146.

Paterson, M. 2010. "Legitimation and Accumulation in Climate Change Governance." New Political Economy 15: 345-368.

Paterson, M. 2012. "Who and What are Carbon Markets for? Politics and the Development of Climate policy." Climate Policy 12: 82-97.

People's Government of Chongqing Municipality. 2011. Notice of the People's Government of Chongqing Municipality about the Implementation Work Plan and Task Assignment for Carbon Emission Trading in Chongqing Municipality (No. 20). (in Chinese) Chongqing: People's Government of Chongqing Municipality.

People's Government of Guangdong Province. 2012. Notice of the People's Government of Guangdong Province about the Implementation of the Carbon Emission Trading Trial in Guangdong Province, (No. 264). (in Chinese) Guangdong : People's Government of Guangdong Province.

People's Government of Hubei Province. 2013. Notince of the People's Government of Hubei Province about the Implementation Plan of the Carbon Emission Trading Trial in Hubei Province, (No. 9). (in Chinese) Hubei: People's Government of Hubei Province.

People's Government of Tianjin Municipality. 2013. Notice of the People's Government of Tianjin Municipality about the Implementation Plan of the Carbon Emission Trading Trial in Tianjin Municipality, (No. 12). (in Chinese) Tianjin: People's Government of Tianjin Municipality.

Perdan, S. and A. Azapagic. 2011. "Carbon Trading: Current Schemes and Future Developments." Energy Policy 39: 6040-6054.

Productivity Commission. 2011. Carbon Emission Policies in Key Economies. Canberra.

Qian, G. Q. and L. Jin. 2012. "Progress and Prospect of the Construction of China's Carbon Trading Market." In Green Book of Climate Change: Annual Report on Actions to Address Climate Change, edited by W. Wang and G. Zheng. Beijing: Social Sciences Academic Press, 114-122.

Qin, T. 2012. Climate Change and Emission Trading Systems (ETS): China's Perspective and International Experiences. (No. 102). (en) Shanghai 2012. Shanghai: Konrad-Adenauer-Stiftung China. 
Richerzhagen, C. and I. Scholz. 2008. "China's Capacities for Mitigating Climate Change." World Development 36: 308-324.

Rudolph, S. and F. Schneider. 2013. "Political Barriers of Implementing Carbon Markets in Japan: A Public Choice Analysis and the Empirical Evidence before and after the Fukushima Nuclear Disaster." Environmental Economics and Policy Studies 15: 211-235.

Spaargaren, G. and A. P. J. Mol. 2013. "Carbon Flows, Carbon Markets, and Low-carbon Lifestyles: Reflecting on the Role of Markets in Climate Governance." Environmental Politics 22: 174-193.

Spash, C. L. and A. Y. Lo. 2012. Australia's Carbon Tax: A Sheep in Wolf's Clothing? The Economic and Labour Relations Review. 23: 67-86.

State Council. 2008. China's Policies and Actions for Addressing Climate Change. (in Chinese)Beijing: State Council.

State Council. 2010. Decision of the State Council to Accelerate the Development of Emerging Strategic Industries, (No. 32). (in Chinese). Beijing: State Council.

State Council. 2011a. Decision of the State Council to Strengthen the Discipline of Various Exchanges to Avoid Financial Risks, (No. 38). (in Chinese) Beijing: State Council.

State Council. 2011b. The Twelfth Five-Year Plan for National Environmental Protection, (No. 42). (in Chinese). Beijing: State Council.

Tao, J. and D. N. Y. Mah. 2009. "Between Market and State: Dilemmas of Environmental Governance in China's Sulphur Dioxide Emission Trading System." Environment and Planning C: Government and Policy 27: 175-188.

The Climate Group. 2013. Shaping China's Climate Finance Policy. London: The Climate Group.

Tokyo Metropolitan Government. 2010. Tokyo Cap-and-Trade Program: Japan's First Mandatory Emissions Trading Scheme. Tokyo: Bureau of Environment.

Tsang, S. and A. Kolk. 2010. "The Evolution of Chinese Policies and Governance Structures on Environment, Energy, and Climate." Environmental Policy and Governance 20: 180-196.

Wang, Q. 2013. China Has the Capacity to Lead in Carbon Trading. Nature. 493(January 17): 273.

Wang, Y., Q. Liu, and B. Chen. 2012. 2012 China Climate Finance Report: Climate Capital Flow. Beijing: Central University of Finance and Economics and The Climate Group.

Wu, Q. 2011. "Policy and Politics of a Carbon Market in China." In Greenhouse Gas Market Report 2011: Asia and Beyond: The Roadmap to Global Carbon \& Energy Markets, edoted by J. Peetermans. Genève, Switzerland: International Emissions Trading Association, 22-25.

Xinhua News Agency. 2011. "Domestic Carbon Exchanges Blossom and Most Come at a Loss." September 28. Accessed September 17, 2012. http://news.xinhuanet.com/fortune/201109/28/c_122097917.htm (in Chinese).

$\mathrm{Yu}, \mathrm{G}$. and R. Elsworth. 2012. Turning the Tanker: China's Changing Economic Imperatives and Its Tentative Look to Emissions Trading. London: Sandbag Climate Campaign.

Yu, J. 2012. "NGOs and Climate Change." In China's Climate Change Policies, edited by W. Wang and G. Zheng. Oxon, UK: Routledge, 104-115.

Zhang, Z. 2007. "Why Has China Not Embraced a Global Cap-and-trade Regime?" Climate Policy 7: 166170.

Zhang, Z. 2010. "China in the Transition to a Low-carbon Economy" Energy Policy 38: 6638-6653.

Zhao, X., F. Wang, and M. Wang. 2012. "Large-scale Utilization of Wind Power in China: Obstacles of Conflict between Market and Planning." Energy Policy 48: 222-232. 
'Source: United Nations Framework Convention on Climate Change (UNFCCC). Accessed August 31, 2013. http://cdm.unfccc.int/Statistics.

ii Additionality means that whether or not the claimed emissions reductions would still materialize if the project did not proceed.

iii "These include "environment," "energy," and "emission rights" exchanges engaging in carbon trading activities.

iv FYP is formally known as "Five-Year Plan for National Economic and Social Development." It is a periodic guiding document and the most prominent strategic blueprint for the country that prescribes national economic and social directions and policy priorities. FYP was renamed to "Five-Year Guideline" since 2006, although it is still referred as FYP in English.

${ }^{v}$ Since Shenzhen falls within the jurisdictional boundary of Guangdong Province, its GDP and population form part of the Guangdong estimates and are therefore excluded from the calculation to avoid double counting.

${ }^{v i} A$ full list of DNAs is available from the CDM official website hosted by the UNFCCC:

http://cdm.unfccc.int/DNA/bak/index.html\#T

vii Available online and in Chinese language: People's Government of Chongqing Municipality (2011), People's Government of Guangdong Province (2012), People's Government of Hubei Province (2013), People's Government of Tianjin Municipality (2013). The ETS implementation notices released by Shanghai and Shenzhen municipalities did not clearly specify the assignment of tasks among departments.

viii Formally known as the Conference of the Parties (COP) to the UNFCCC.

${ }^{\text {ix }}$ As of September 30, 2013. See http://icapcarbonaction.com for updates. 